\title{
Ḥāfez de Chiraz (1325-1390). Cent un ghazals amoureux. Traduit du persan, présenté et annoté par Gilbert Lazard
}

Ève Feuillebois-Piérunek

\section{(2) OpenEdition}

1 Journals

\section{Édition électronique}

URL : http://journals.openedition.org/abstractairanica/40956

DOI : 10.4000/abstractairanica.40956

ISSN : 1961-960X

Éditeur :

CNRS (UMR 7528 Mondes iraniens et indiens), Éditions de l'IFRI

\section{Édition imprimée}

Date de publication : 1 décembre 2013

ISSN : 0240-8910

\section{Référence électronique}

Ėve Feuillebois-Piérunek, « Hāfez de Chiraz (1325-1390). Cent un ghazals amoureux. Traduit du persan, présenté et annoté par Gilbert Lazard », Abstracta Iranica [En ligne], Volume 32-33 | 2013, document 426, mis en ligne le 01 juillet 2016, consulté le 29 septembre 2020. URL : http://

journals.openedition.org/abstractairanica/40956 ; DOI : https://doi.org/10.4000/abstractairanica. 40956

Ce document a été généré automatiquement le 29 septembre 2020.

Tous droits réservés 


\section{Hậfez de Chiraz (1325-1390). Cent un ghazals amoureux. Traduit du persan, présenté et annoté par Gilbert Lazard}

Ève Feuillebois-Piérunek

\section{RÉFÉRENCE}

Ḥăfez de Chiraz (1325-1390). Cent un ghazals amoureux. Traduit du persan, présenté et annoté par Gilbert Lazard, Paris, Gallimard, 2010, 241 p. (Connaissance de l'Orient)

1 Une nouvelle et très élégante traduction française d'un choix de ġazals de Ḥâfez, d'un tout autre esprit que celle, intégrale et plus proche du texte, de C.-H. de Fouchécour : les deux se complètent d'ailleurs bien pour comprendre les finesse de l'écriture de cet auteur difficile. L'introduction définit poétiquement le gazal comme « un monde fictif peuplé et meublé de tout un personnel et tout un matériel symboliques: amoureux éperdus, idoles irrésistibles, gardiens inflexibles, jardins paradisiaques, pleins de fleurs merveilleuses et d'oiseaux enchanteurs, envahis de brises parfumées et de zéphyrs messagers». L'Amour y est Roi, générateur d'une souffrance exquise et d'une jouissance déchirante. Amour d'ivresse et d'extase. L'ambiguïté du poète, fustigeant les hypocrites et les dévots et dont on ne peut savoir avec précision s'il est un mystique, fait partie de son charme et de son mystère. Une traduction et une présentation attrayantes en direction du grand public. 


\section{AUTEURS}

\section{ÈVE FEUILLEBOIS-PIÉRUNEK}

Université Sorbonne Nouvelle-Paris 3/Mondes iranien et indien, Paris 